\title{
Physical properties of safflower grains. Part II: Volumetric shrinkage
}

\author{
Elton A. S. Martins ${ }^{1}$, André L. D. Goneli ${ }^{1}$, Alexandre A. Gonçalves ${ }^{1}$, \\ Cesar P. Hartmann Filho ${ }^{1}$, Jerusa Rech ${ }^{1} \&$ Guilherme C. Oba ${ }^{1}$ \\ ${ }^{1}$ Universidade Federal da Grande Dourados/Faculdade de Ciências Agrárias. Dourados, MT. E-mail: elton_asm@hotmail.com (Corresponding author); \\ andregoneli@ufgd.edu.br; alexandre_alvesg@hotmail.com; cphartmann21@hotmail.com; jerusarech@hotmail.com; guilherme_oba@hotmail.com
}

\section{Key words:}

Carthamus tinctorius L.

volume

water content

\begin{abstract}
A B S T R A C T
Agricultural products usually have their size reduced during the drying process. The quantification of the reduction in the dimensions is important for the development and optimization of equipment for the post-harvest of the product. The aim of the present study was to evaluate the effect of the variation in the moisture content during drying on the volumetric shrinkage of safflower grains and their respective axes. Safflower grains were harvested with an initial moisture content of approximately 0.445 decimal d.b. (dry basis) and subjected to drying in an oven with forced air circulation at $40{ }^{\circ} \mathrm{C}$, until the grains reached a final moisture content of $0.073 \pm 0.008$ decimal d.b. During drying, the contraction of the axes, unit volumetric shrinkage and volumetric shrinkage of the mass of safflower grains were determined at different moisture contents. Based on these results, it can be concluded that reducing the moisture content causes a reduction in the axes of safflower grains and, consequently, reductions in the unit volumetric shrinkage and volumetric shrinkage of the mass of approximately 16 and $13 \%$, respectively, and both variables can be represented by the linear shrinkage model.
\end{abstract}

Palavras-chave:

Carthamus tinctorius L.

volume

teor de água

\section{Propriedades físicas dos grãos de cártamo. Parte II: Contração volumétrica}

\begin{abstract}
R E S U M O
Normalmente, os produtos agrícolas têm suas dimensões reduzidas durante o processo de secagem. A quantificação da redução dessas dimensões é importante para o desenvolvimento e otimização de equipamentos destinados à pós-colheita do produto. Em virtude disto, objetivou-se, com o presente trabalho, avaliar o efeito da variação do teor de água durante a secagem sobre a contração volumétrica dos grãos de cártamo e de seus respectivos eixos. Foram utilizados grãos de cártamo colhidos com teor de água inicial de aproximadamente 0,445 decimal b.s. (base seca) e submetidos à secagem em estufa com circulação forçada de ar, na temperatura de $40^{\circ} \mathrm{C}$, até os grãos atingirem o teor de água final de $0,073 \pm 0,008$ decimal b.s. Durante a secagem, os índices de contração dos eixos e contração volumétrica unitária e da massa de grãos de cártamo foram determinados em diferentes teores de água. Com base nos resultados obtidos pode-se concluir que a redução do teor de água causa redução dos eixos dos grãos de cártamo; consequentemente, a redução dos valores do índice de contração volumétrica da massa e unitária de aproximadamente 16 e 13\%, respectivamente, em que ambas as variáveis podem ser representadas pelo modelo de contração linear.
\end{abstract}




\section{INTRODUCTION}

Among the oilseed crops currently exploited in the world, safflower (Carthamus tinctorius L.) has become increasingly prominent because, besides showing great potential as raw material for biodiesel production due to its high oil content $(20$ to $45 \%$ ), it has various uses in the industry, such as medicinal purposes, human consumption and animal feed (Ekin, 2005; Coşge et al., 2007; Emongor, 2010).

Despite this relevance, various points in the production chain of the crop require further studies. Safflower, as most crops, also needs to undergo the drying process after harvest, because of the necessity to reduce its moisture content for a safer and more effective storage. However, reducing moisture content in an agricultural product affects its physical properties, altering its mass, dimensions and, consequently, its volume. Hence, it leads to important considerations, as in the elaboration of projects of equipment intended especially for the post-harvest of the product.

The reduction in the characteristic dimensions of grains and seeds is called volumetric shrinkage, and the reduction in their moisture content through the drying process is the main cause of this effect. Volumetric shrinkage is rarely insignificant during the dehydration process (Koç et al., 2008) and the volume is normally the physical characteristic that most suffers during the drying process.

The shrinkage or contraction of the agricultural products during drying is evaluated, in general, through the volumetric shrinkage, which determines the ratio between the volume and the initial volume for certain moisture contents of the grain or seed. The analysis of this variable is very important during the drying process, because it allows to estimate the variation of the volume occupied by the mass of grains, as the moisture content reduces (Siqueira et al., 2012a).

In this context, the present study aimed to evaluate the contraction of the axes, unit volumetric shrinkage and volumetric shrinkage of the mass of safflower grains during drying.

\section{Material ANd Methods}

The present study was carried out at the Laboratory of Pre-Processing and Storage of Agricultural Products, of the Faculty of Agrarian Sciences - FCA, belonging to the Federal University of Grande Dourados - UFGD, in the municipality of Dourados, MS, Brazil, from August to September 2013.

Safflower grains cultivated at the UFGD Experimental Farm were used in the experiment. The safflower capitula were manually harvested, selecting only those that had already reached maturation. Threshing was manually performed, followed by a new selection, removing all defective grains to avoid any type of undesirable influence that might interfere with the research results.

After threshing, the safflower grains were placed in lowdensity plastic packages and stored in B.O.D chambers at temperature of $3.5^{\circ} \mathrm{C}$, to avoid water exchange in the form of vapor between the product and the external environment, in order to maintain and homogenize the moisture content of the product. The safflower grains showed an initial moisture content of approximately 0.445 decimal d.b. (dry basis).

The safflower grains were dried in a forced-air oven at the temperature of $40^{\circ} \mathrm{C}$, with the single purpose of reducing their moisture content. The reduction of moisture content for the mass shrinkage determination was monitored using a scale with 0.01-g resolution, while the determinations of contraction of the axes and unit volumetric shrinkage were monitored using a scale with 0.001 -g resolution, through the gravimetric method (mass loss), until the grains reached the final moisture content of 0.073 \pm 0.008 decimal d.b. The initial and final moisture contents of safflower grains were determined by the gravimetric method in an oven at $105 \pm 1{ }^{\circ} \mathrm{C}$, for $24 \mathrm{~h}$, in two replicates (Brasil, 2009).

The unit volumetric shrinkage and contraction of the axes were determined by randomly selecting 18 safflower grains, which were individually dried. For each moisture content sampled during the drying process, a digital caliper with resolution of $0.01 \mathrm{~mm}$ was used to measure the perpendicular diameters of the product (Figure 1), length (a), width (b) and thickness (c), all in $\mathrm{mm}$.

The volume of each grain, along the drying process, was determined using Eq. 1, proposed by Jain \& Bal (1997), considering the form of the product as a conical-spherical body.

$$
\begin{gathered}
\mathrm{V}_{\mathrm{g}}=\frac{\pi \mathrm{D}^{2} \mathrm{a}^{2}}{6(2 \mathrm{a}-\mathrm{D})} \\
\mathrm{D}=(\mathrm{b} \times \mathrm{c})^{0.5}
\end{gathered}
$$

where:

$\mathrm{V}_{\mathrm{g}}$ - volume of the grain, $\mathrm{mm}^{3}$; and,

$D^{g}$ - geometric mean between the measurements " $b$ " and "c" of the product, $\mathrm{mm}$.

The contraction of the axes of safflower grains (length a; width - b; and thickness - c) was calculated by the ratio between the dimension of the axis at certain instant and its initial dimension, using Eq. 3.

$$
\Psi_{\mathrm{x}}=\frac{\mathrm{X}}{\mathrm{X}_{0}}
$$

where:

$\psi_{\mathrm{x}} \quad$ - contraction of the studied axis, dimensionless;

$\mathrm{X}$ - dimension of the axis at a certain instant, $\mathrm{mm}$; and,

$\mathrm{X}_{0} \quad$ - initial dimension of the axis, $\mathrm{mm}$.

The unit volumetric shrinkage and volumetric shrinkage of the mass of safflower grains were determined by calculating
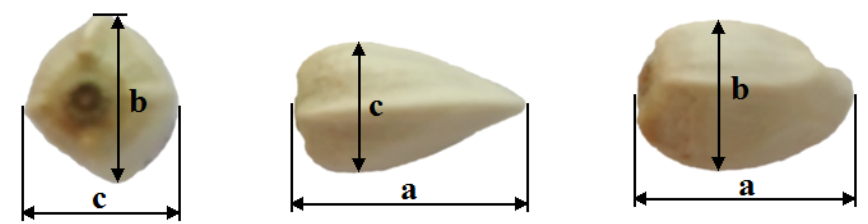

Figure 1. Representation of the perpendicular diameters of the safflower grains 
the ratio between the volume of the product at a certain instant and its initial volume (Eq. 4), along the drying process.

$$
\Psi=\frac{\mathrm{V}}{\mathrm{V}_{0}}
$$

where:

$\Psi \quad$ - volumetric shrinkage, dimensionless;

$\mathrm{V}$ - volume (of the mass or grain) at a certain instant, $\mathrm{mm}^{3}$; and,

$\mathrm{V}_{0} \quad$ - initial volume (of the mass or grain), $\mathrm{mm}^{3}$.

The reduction in the volume of the mass was monitored based on an initial volume of $500 \mathrm{~cm}^{3}(500 \mathrm{~mL})$ of safflower grains. There was a reduction of this volume along the drying process, the mass of grains was transferred to a $500-\mathrm{cm}^{3}$ graduated cylinder and the volume was recorded for different moisture contents during drying. For each moisture content, the volume of the mass in the $500-\mathrm{cm}^{3}$ graduated cylinder was measured six times and its value resulted from the mean of these six measurements.

Mathematical models (Table 1) were fitted to the experimental data of volumetric shrinkage of the mass and unit volumetric shrinkage of the safflower grains.

Table 1. Mathematical models used to represent the unit volumetric shrinkage and volumetric shrinkage of the mass of safflower grains as a function of the moisture content

\begin{tabular}{llc}
\hline \multicolumn{1}{c}{ Designation of the model } & \multicolumn{1}{c}{ Model } \\
Modified Bala \& Woods (1984) & $\Psi=1-\mathrm{a}\left\{1-\exp \left[-\mathrm{b}\left(\mathrm{U}_{0}-\mathrm{U}\right)\right]\right\}$ & $(5)$ \\
Corrêa et al. (2004) & $\Psi=1 /[\mathrm{a}+\mathrm{b} \exp (\mathrm{U})]$ & $(6)$ \\
Exponential & $\Psi=\mathrm{a} \exp (\mathrm{b} \mathrm{U})$ & $(7)$ \\
Linear & $\Psi=\mathrm{a}+\mathrm{b} U$ & $(8)$ \\
Polynomial & $\Psi=\mathrm{a}+\mathrm{b} \mathrm{U}+\mathrm{c} \mathrm{U}^{2}$ & $(9)$ \\
Rahman (1995) & $\Psi=1+\beta\left(\mathrm{U}-\mathrm{U}_{0}\right)$ & $(10)$ \\
\hline
\end{tabular}

where:

$\mathrm{U}$ - moisture content of the product, decimal d.b.;

$\mathrm{U}_{0} \quad$ - initial moisture content of the product, decimal d.b.;

a, b, c - parameters that depend on the product, dimensionless; and,

$\beta$ - volumetric shrinkage coefficient, dimensionless.

The experimental data relative to the axes of safflower grains were subjected to linear regression analysis. The regression models were fitted using the computer program SigmaPlot 11.0, based on the selection criteria of significance level of the model by $F$ test and coefficient of determination $\left(\mathrm{R}^{2}\right)$.

The experimental data relative to the unit volumetric shrinkage and volumetric shrinkage of the mass were subjected to nonlinear and linear regression analyses, through the GaussNewton method. The mathematical models were fitted to the experimental data using the computer program Statistica 8.0.

The models to represent the volumetric shrinkage were selected considering the highest magnitudes of the coefficient of determination $\left(\mathrm{R}^{2}\right)$ and reduced values of the mean relative error $(\mathrm{P})$ and standard deviations of the estimate (SE). The values of the mean relative error $(\mathrm{P}$, in \%) and standard deviation of the mean (SE, decimal) were calculated according to Eqs. 11 and 12:

$$
\begin{aligned}
& \mathrm{P}=\frac{100}{\mathrm{n}} \sum_{\mathrm{i}=1}^{\mathrm{n}}\left(\frac{|\mathrm{Y}-\hat{\mathrm{Y}}|}{\mathrm{Y}}\right) \\
& \mathrm{SE}=\sqrt{\frac{\sum_{\mathrm{i}=1}^{\mathrm{n}}(\mathrm{Y}-\hat{\mathrm{Y}})^{2}}{\mathrm{DF}}}
\end{aligned}
$$

where:

$$
\begin{array}{ll}
\mathrm{n} & \text { - number of experimental observations; } \\
\mathrm{Y} & \text { - experimental value; } \\
\hat{Y} & \text { - value estimated by the model; and, } \\
\mathrm{DF} & \text { - degrees of freedom of the model. }
\end{array}
$$

\section{Results AND Discussion}

A typical behavior of the agricultural products is the reduction of volume during the drying process (Figure 2A), which has been observed by many researchers in a series of crops, such as pistachio, castor bean, rice, jatropha and

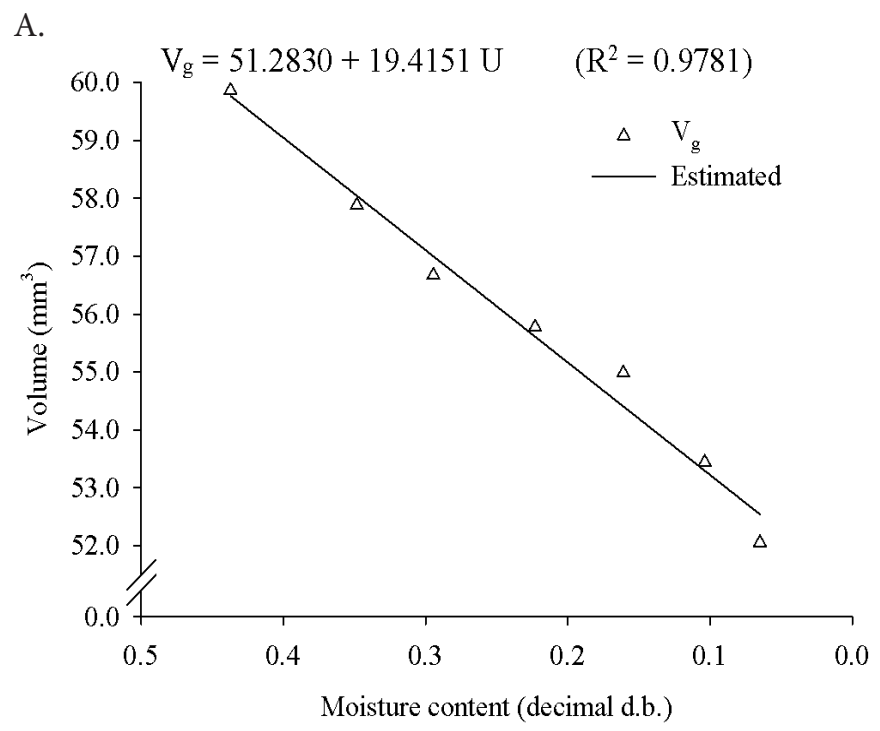

B.

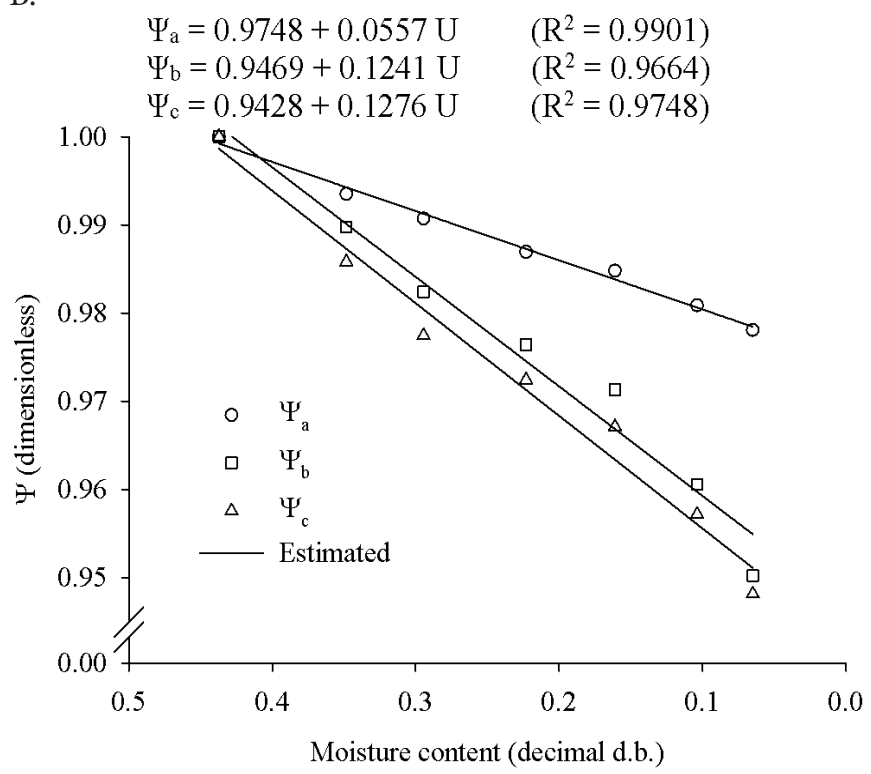

Figure 2. Volume (A) and contraction of the axes (B) of safflower grains during drying 
peanut (Razavi et al., 2007; Goneli et al., 2008; Kibar et al., 2010; Siqueira et al., 2012b; Araújo et al., 2014). Commonly, this fact is related to the more or less intense reduction of the parameters relative to the size of the product, more specifically of its perpendicular axes, referring to its length, width and thickness, as already confirmed by Botelho et al. (2016), for example, in coffee fruits.

According to the shrinkage of the characteristic dimensions of safflower grains (Figure 2B), the width (b) and thickness (c) contracted, in the same proportion, by approximately $5.0 \%$, in relation to their respective initial values, while the length (a) contracted by approximately $2.0 \%$, less than half of the other dimensions, for a moisture content range from 0.44 to 0.06 decimal d.b.

Seifi et al. (2010), in a study with safflower grains, also found that the product dimension with lowest reduction was the length. The lower shrinkage of length, compared with width and thickness, for safflower grains, can be attributed to the direction of the fibers in the tegument of these grains, as can be observed in Figure 1, thus offering greater resistance to the shrinkage of this dimension of the product.

Araújo et al. (2014), evaluating the shrinkage of the characteristic dimensions of peanut grains, observed a similar behavior to that of the present study, in which one of the dimensions reduced more than the others. However, in the peanut grains, the thickness was the dimension that reduced more sharply, while length and width reduced in the same proportion.

The shrinkages of the orthogonal axes of agricultural products normally exhibit a slight non-uniformity during the drying process, a fact observed in other products, such as castor bean fruits (Goneli et al., 2011), cucurbit seeds (Milani et al., 2007) and sugarbeet seeds (Dursun et al., 2007).

All models used to predict the volumetric shrinkage of the mass of safflower grains showed high coefficients of determination $\left(\mathrm{R}^{2}\right)$ (Table 2 ), besides reduced values of standard deviation of the estimate (SE); the lower the values of this statistical parameter, the better the quality of the model fit in relation to the observed data. According to Mohapatra \& Rao (2005), models with mean relative errors (P) lower than $10 \%$ are adequate to represent the process in question. Thus, all analyzed models can represent the volumetric shrinkage of the mass of safflower grains during drying (Table 2).

Among the six analyzed models to represent the volumetric shrinkage of the mass of safflower grains during drying, the models linear, polynomial and Rahman (1995) stood out with high magnitudes of $\mathrm{R}^{2}$ and reduced values of $\mathrm{SE}$ and $\mathrm{P}$, and the linear model was selected because of its simplicity (Figure 3A). Resende et al. (2005) and Oliveira et al. (2013) also used the
A.

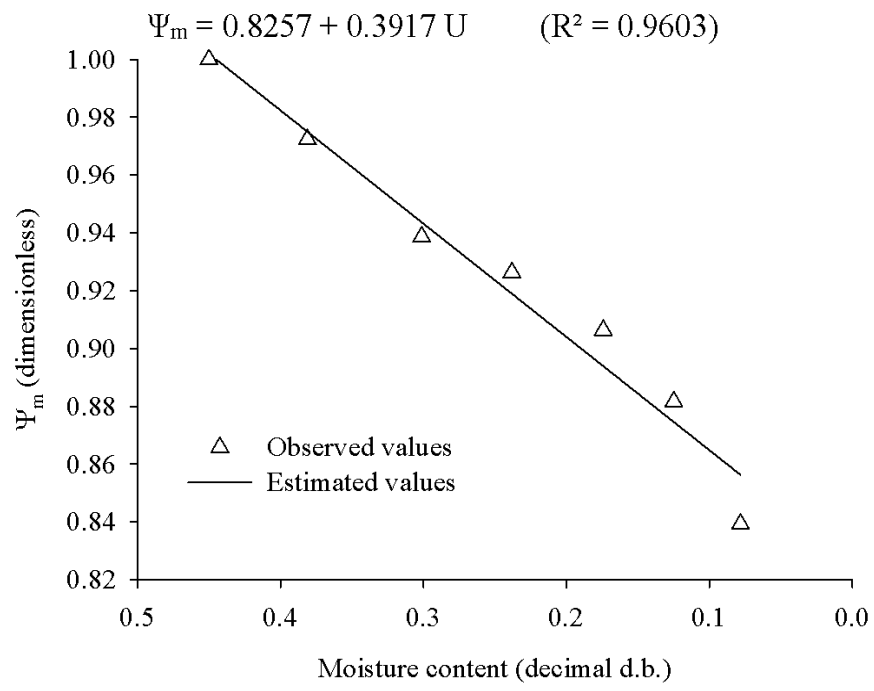

B.

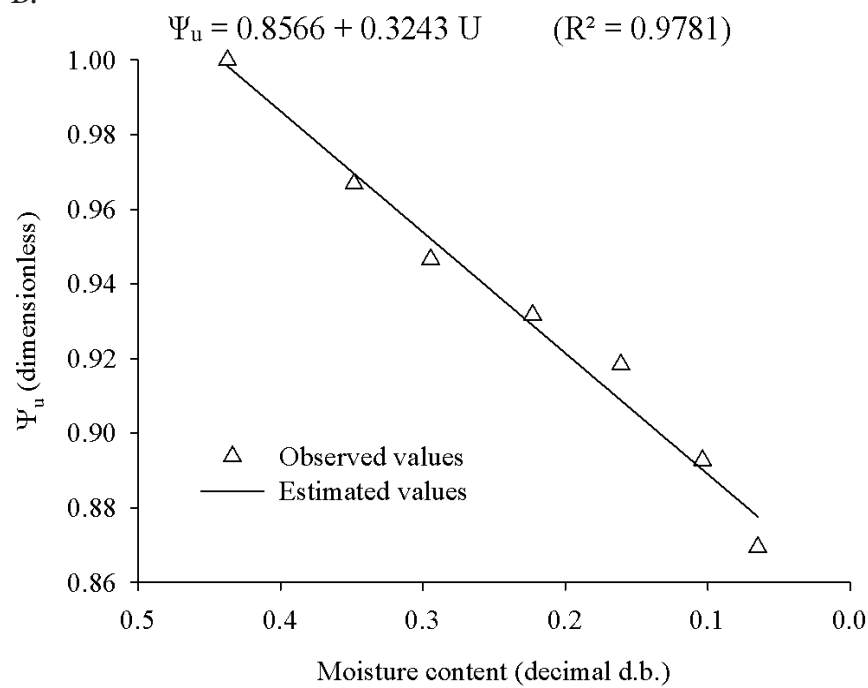

Figure 3. Observed and estimated values for the volumetric shrinkage of the mass (A) and unit volumetric shrinkage (B) of safflower grains during drying

linear model to represent the shrinkage of the mass of bean and soybean grains, respectively.

As observed in Figure 3A, the mass of safflower grains contracted by approximately $16 \%$, in relation to its initial volume, for a reduction in the moisture content from 0.45 to 0.08 decimal d.b.

Still in Table 2, for the unit volumetric shrinkage, all models showed reduced values of standard deviation of the estimate (SE) and mean relative errors (P) lower than 10\%, emphasizing that these models can represent the studied process and, in addition, all models showed high coefficients of determination $\left(\mathrm{R}^{2}\right)$.

Table 2. Statistical parameters for the models of volumetric shrinkage of safflower grains

\begin{tabular}{|c|c|c|c|c|c|c|}
\hline \multirow[b]{2}{*}{ Designation of the Model } & \multicolumn{3}{|c|}{ Volumetric shrinkage of the mass } & \multicolumn{3}{|c|}{ Unit volumetric shrinkage } \\
\hline & $\begin{array}{c}\text { SE } \\
\text { (decimal) }\end{array}$ & $\begin{array}{c}P \\
(\%)\end{array}$ & $\begin{array}{c}\mathrm{R}^{2} \\
\text { (decimal) }\end{array}$ & $\begin{array}{c}\text { SE } \\
\text { (decimal) }\end{array}$ & $\begin{array}{c}P \\
(\%)\end{array}$ & $\begin{array}{c}\mathrm{R}^{2} \\
\text { (decimal) }\end{array}$ \\
\hline Modified Bala \& Woods (1984) & 0.0109 & 0.8056 & 0.9597 & 0.0066 & 0.5080 & 0.9776 \\
\hline Corrêa et al. (2004) & 0.0143 & 1.0188 & 0.9301 & 0.0085 & 0.5771 & 0.9628 \\
\hline Exponential & 0.0115 & 0.8959 & 0.9547 & 0.0068 & 0.5115 & 0.9762 \\
\hline Linear & 0.0108 & 0.8570 & 0.9603 & 0.0065 & 0.5127 & 0.9781 \\
\hline Polynomial & 0.0101 & 0.7610 & 0.9652 & 0.0071 & 0.5131 & 0.9743 \\
\hline Rahman (1995) & 0.0099 & 0.8056 & 0.9665 & 0.0060 & 0.5080 & 0.9813 \\
\hline
\end{tabular}


Based on the statistical parameters presented in Table 2, among the six analyzed models to estimate the unit volumetric shrinkage of safflower grains, the models Modified Bala \& Woods (1984), linear and Rahman (1995) stood out for showing high magnitudes of $\mathrm{R}^{2}$ and reduced values of $\mathrm{SE}$ and P. Among these three, the linear model was selected because of its simplicity to represent the unit shrinkage of safflower grains during the drying process. Afonso Júnior \& Corrêa (2000) also used the Linear model to estimate the values of the unit volumetric shrinkage for two popcorn varieties.

The safflower grains contracted by approximately $13 \%$, in relation to their initial volume, due to the reduction in moisture content from 0.44 to 0.06 decimal d.b. (Figure $3 \mathrm{~B}$ ). The unit shrinkage was slightly inferior to the shrinkage of the mass of safflower grains. This fact can be explained by the fact that the grains accommodate in the mass, so that there are fewer empty spaces between the grains, since they reduce their size during drying.

\section{Conclusions}

1. The removal of water during drying favors the reduction in the characteristic dimensions of the product (length, width and thickness), and length is the dimension with lowest contraction.

2 . The reduction of moisture content influences the volumetric shrinkage of the mass and unit volumetric shrinkage of safflower grains, causing reductions of approximately 16 and $13 \%$, respectively, and both variables can be represented by the linear shrinkage model.

\section{ACKNOWLEDGMENTS}

The authors thank the Foundation to Support the Development of Education, Science and Technology of the State of Mato Grosso do Sul - FUNDECT and the Coordination for the Improvement of Higher Education Personnel - CAPES for the financial support for the development and dissemination of this work.

\section{Literature Cited}

Afonso Júnior, P. C.; Corrêa, P. C. Cinética da contração volumétrica dos grãos de duas cultivares de milho-pipoca durante o processo de secagem. Revista Brasileira de Produtos Agroindustriais, v.2, p.6165, 2000. https://doi.org/10.15871/1517-8595/rbpa.v2n1p61-65

Araujo, W. D.; Goneli, A. L. D.; Souza, C. M. A.; Gonçalves, A. A.; Vilhasanti, H. C. B. Propriedades físicas dos grãos de amendoim durante a secagem. Revista Brasileira de Engenharia Agrícola e Ambiental, v.18, p.279-286, 2014. https://doi.org/10.1590/S141543662014000300006

Bala, B. K.; Woods, J. L. Simulation of deep bed malt drying. Journal of Agricultural Engineering Research, v.30, p.235-244, 1984. https:// doi.org/10.1016/S0021-8634(84)80024-4

Brasil. Ministério da Agricultura, Pecuária e Abastecimento. Secretaria de Defesa Agropecuária. Regras para análise de sementes. Brasília: MAPA, 2009. 395p.

Botelho, F. M.; Corrêa, P. C.; Botelho, S. C. C.; Vargas Elías, G. A.; Almeida, M. D. S. D.; Oliveira, G. H. H. de. Propriedades físicas de frutos de café robusta durante a secagem: Determinação e modelagem. Coffee Science, v.11, p.65-75, 2016.
Coşge, B.; Gürbüz, B.; Kiralan, M. Oil content and fatty acid composition of some safflower (Carthamus tinctorius L.) varieties sown in spring and winter. International Journal of Natural and Engineering Sciences, v.1, p.11-15, 2007.

Dursun, I.; Tugrul, K. M.; Dursun, E. Some physical properties of sugarbeet seed. Journal of Stored Products Research, v.43, p.149155, 2007. https://doi.org/10.1016/j.jspr.2006.03.001

Ekin, Z. Resurgence of safflower (Carthamus tinctorius L.) utilization: A global view. Journal of Agronomy, v.4, p.83-87, 2005. https:// doi.org/10.3923/ja.2005.83.87

Emongor, V. Safflower (Carthamus tinctorius L.) the underutilized and neglected crop: A review. Asian Journal of Plant Sciences, v.9, p.299-306, 2010. https://doi.org/10.3923/ajps.2010.299.306

Goneli, A. L. D.; Corrêa, P. C.; Botelho, F. M.; Oliveira, G. H. H.; Santos, E. S. Propriedades físicas dos frutos de mamona durante a secagem. Revista Brasileira de Armazenamento, v.33, p.148155, 2008.

Goneli, A. L. D.; Corrêa, P. C.; Magalhães, F. E. A.; Baptestini, F. M. Contração volumétrica e forma dos frutos de mamona durante a secagem. Acta Scientiarum. Agronomy, v.33, p.1-8, 2011. https:// doi.org/10.4025/actasciagron.v33i1.4629

Jain, R. K.; Bal, S. Properties of pearl millet. Journal of Agricultural Engineering Research, v.66, p.85-91, 1997. https://doi.org/10.1006/ jaer.1996.0119

Kibar, H.; Öztürk, T.; Esen, B. The effect of moisture content on physical and mechanical properties of rice (Oryza sativa L.). Spanish Journal of Agricultural Research, v.8, p.741-749, 2010. https://doi.org/10.5424/sjar/2010083-1273

Koç, B.; Eren, I.; Ertekin, F. K. Modelling bulk density, porosity and shrinkage of quince during drying: The effect of drying method. Journal of Food Engineering, v.85, p.340-349, 2008. https://doi. org/10.1016/j.jfoodeng.2007.07.030

Milani, E.; Seyed, M.; Razavi, A.; Koocheki, A.; Nikzadeh, V.; Vahedi, N.; Moeinfard, M.; Gholamhosseinpour, A. Moisture dependent physical properties of cucurbit seeds. International Agrophysics, v.21, p.157-168, 2007.

Mohapatra, D.; Rao, P. S. A thin layer drying model of parboiled wheat. Journal of Food Engineering, v.66, p.513-518, 2005. https://doi. org/10.1016/j.jfoodeng.2004.04.023

Oliveira, D. E. C.; Resende, O.; Smaniotto, T. A. S.; Siqueira, V. C.; José Neto, C. A. Alterações morfométricas em grãos de soja durante o processo de secagem. Semina: Ciências Agrárias, v.34, p.975-984, 2013. https://doi.org/10.5433/1679-0359.2013v34n3p975

Rahman, S. Physical properties of foods. Boca Raton: CRC Press LLC, 1995. 500p.

Razavi, S. M. A.; Rafe, A.; Moghaddam, T. M.; Amini, A. M. Physical properties of pistachio nut and its kernel as a function of moisture content and variety. Part II. Gravimetrical properties. Journal of Food Engineering, v.81, p.218-225, 2007. https://doi. org/10.1016/j.jfoodeng.2006.10.024

Resende, O.; Corrêa, P. C.; Goneli, A. L. D.; Cecon, P. R. Forma, tamanho e contração volumétrica do feijão (Phaseolus vulgaris L.) durante a secagem. Revista Brasileira de Produtos Agroindustriais, v.7, p.15-24, 2005. https://doi.org/10.15871/1517-8595/rbpa. v7n1p15-24

Seifi, M. R.; Alimardani, R.; Akram, A.; Asakereh, A. Moisture-depend physical properties of safflower (Goldasht). Advance Journal of Food Science and Technology, v.2, p.340-345, 2010. 
Siqueira, V. C.; Resende, O.; Chaves, T. H. Determination of the volumetric shrinkage in jatropha seeds during drying. Acta Scientiarum. Agronomy, v.34, p.231-238, 2012a. https://doi. org/10.4025/actasciagron.v34i3.14402
Siqueira, V. C.; Resende, O.; Chaves, T. H.; Soares, F. A. L. Forma e tamanho dos frutos de pinhão-manso durante a secagem em cinco condições de ar. Revista Brasileira de Engenharia Agrícola e Ambiental, v.16, p.864-870, 2012b. https://doi.org/10.1590/S1415-43662012000800008 